\title{
The impact of external institutional shocks on Russian regions
}

\author{
Irina V. Danilova ${ }^{1}$, Olga A. Bogdanova ${ }^{1}$, Angelika V. Karpushkina², \\ Tatiana M. Karetnikova ${ }^{3, *}$
}

\footnotetext{
${ }^{1}$ State and Municipal Administration South Ural State University (National Research University), Department of Economic Theory, Regional Economy, Russia

2 South Ural State University (National Research University), Department of Economic Security, Russia

${ }^{3}$ State and Municipal Administration South Ural State University (National Research University), Department of Economic Theory, Regional Economy, Russia

* Corresponding author: karetnikova.susu@bk.ru
}

\begin{abstract}
The aim is to assess the susceptibility of the regional economy to shocks associated with unexpected changes in institutional rules, trading instruments, as well as accession to international organizations. The impulse response approach to the study of shocks served as a methodological basis. The authors propose and test a new methodological approach that consists in identifying regions characterized by persistent development or a potential for changing the gross regional product as a response to an external shock impulse. It also allows to determine resonant factors that affect the vulnerability, depth and scale of economic consequences. The study reveals that an external institutional shock influences the economic development of regions in various ways, which is due to a number of vulnerability factors. This leads to the formation of territories that differ in the level of susceptibility to shocks and possess the ability to maintain the trend of economic development.
\end{abstract}

\section{KEYWORDS}

external institutional shocks; vulnerability; vulnerability factors; regional development; persistence

Received: 6 December 2018

Accepted: 9 February 2020

Published: 14 May 2020

Danilova, I. V., Bogdanova, O. A., Karpushkina, A. V., Karetnikova, T. M. (2020): The impact of external institutional shocks on Russian regions. AUC Geographica 55(1), 3-14

https://doi.org/10.14712/23361980.2020.7

(C) 2020 The Authors. This is an open-access article distributed under the terms of the Creative Commons Attribution License (http://creativecommons.org/licenses/by/4.0). 


\section{Introduction}

Under conditions of free trade and intensive interaction among countries, external shocks, due to changes in world markets, political events, and institutional rules, affect countries and, in particular, regions. A shock can have different consequences depending on the degree of region's openness, the level of its development and industrial structure.

An external institutional shock implies unexpected changes in the norms, rules, procedures, and instruments that regulate foreign economic interactions. These changes introduce uncertainty and unpredictability in the reaction of economic subjects (companies, the population) and lead to unpredictable changes in the parameters of regional development, which can be due to the introduction or adjustment of rules in connection with the formation of interstate interaction (for example, customs unions), the accession to international economic organizations (for example, the WTO), and the unexpected application of trading instruments (for example, imposing sanctions).

The authors classified external institutional shocks based on the following criteria:

1) duration (shocks with a limited or unlimited duration);

2) the intensity of the shock impulse (one-time changes or a set of measures; shocks that affect trade and economic relations or investments, or both spheres at the same time).

The practical significance of such a classification is related to the fact that the records of institutional changes causing a shock will allow singling out the following types of shocks: a) Temporary shocks, such as the influence of organizations introduced over a limited period. Theoretically, this kind of shocks do not cause fundamental changes in economic development trends (sanctions are typically imposed for a short period, therefore, sanctions and anti-sanctions are considered temporary shocks. Examples of exceptions are medium-level sanctions against Iran and Russia. b) Permanent shocks associated with a set of institutional changes and having an unlimited duration. These shocks change the institutional regime of foreign economic relations and the trend of regional economic development over a long period (illustrated by the accession of Russia to the WTO, the formation of the Customs Union, and the Eurasian Economic Union).

This article suggests that institutional shocks, as unpredictable events, can cause uneven regional consequences in spatially inhomogeneous large countries, which is due to different sets of economic factors that can strengthen or neutralize the impact of a shock. In other words, the specifics of a regional economy predetermines the scale of consequences (the ability to change or maintain the trend of economic development) and affects the status of the region 'vulnerable' or 'invulnerable' to shocks.
An external institutional shock spreads over a regional economy due to the following factors:

1) changes in the institutional rules of foreign trade or foreign investments affect the decisions of companies and the population on production and consumption;

2) there is a change in the scale of foreign trade operations, import and export prices, business activity, as well as the size and rate of GRP growth.

The properties of persistence/non-persistence were used to assess the effects of a shock on regional development. Persistence is viewed as the preservation of the long-term impact of a shock on the dynamics of the gross product, which is manifested in a significant change in the previous pattern of its growth without the possibility of returning to it in the future. Non-persistence is characterized by shortterm fluctuations of economic parameters followed by a restoration of the current development trend in the economy. Accordingly, depending on their reaction to institutional shocks, regions are divided into two types: vulnerable and invulnerable. The reaction depends on a specific set of 'vulnerability' factors (or factors resonant to a shock).

The economies of a number of countries, including Russia, are currently under the influence of external institutional shocks, namely:

1) the intensification of integration processes and the consistent formation of the Customs and the Eurasian Economic Union, as well as the accession of Russia to the WTO;

2) striking changes in the directions of the trading policy and its instruments: the defensive change in trade barriers during the crisis in 2008-2009, trade and economic sanctions and retaliatory anti-sanctions.

A wide range of external institutional shocks are clearly observed in Russia, a spatially large and heterogeneous country with significant regional inequalities due to natural and climatic conditions, the historical peculiarities of land development and the location of production, regional resources, and transport routes, as well as proximity to major financial centers. The weight of external institutional shocks, in combination with a high level of regional differentiation, predetermines the authors' interest in studying the impact of shocks on a region based on the example of Russia.

The aim of the work is to assess the consequences of the impact of external institutional shocks on the regional economy in countries with high economic differentiation, using the example of Russia. Differentiation presupposes a significant gap in the level of the socio-economic development of regions. The The maximum value of gross regional product per capita exceeds the minimum value of gross regional product per capita 16 times (Bakhtizin, Buchwald, Kolchugin 2017). Regional differentiation, indeed, complicates the process of ensuring the sustainability of the 
economic system, which grants the topic of the study with special relevance.

Based on key channels (trade-economic and investment) of the expansion of external institutional shocks in Russia during the period of 2009-2015, the authors identified the factors that indicate the situation of increasing vulnerability. These factors include the diversification level of the industry structure, the level of foreign trade openness, and the activity of investment ties.

\section{Literature Review}

The study of external shocks intensifies under the conditions of increasing economic openness. The authors of this article used the works of World Bank (2006), Eraydin (2016) and Dominte (2006) as examples, that revealed the impact of changes in world markets and the entire world economy on the stability of economic development. It is especially important to study unexpected institutional changes associated with the rules and instruments of the foreign economic interaction among countries, which is viewed by Shen (2016), Rutherford and Tarr (2006) as an independent factor of destabilizing the economy.

As opposed to deterministic models, the methodological basis for the study of shocks as random influences goes back to the impulse response approach of Slutsky (1937) and Frisch (1933). A shock (impulse) is viewed as a random effect on an economic system, having an exogenous or endogenous nature and triggering the system's adaptation to the impulse.

The research community generally perceives a shock as the prime cause of cyclical fluctuations in economic activity. The study of the mechanisms of the impulse transfer 'along the structural connections of the economic system' (Pilipenko 2011) at the levels of the country and regions is of great scientific interest. In addition to studies of the response to cyclical shocks, there have been attempts to decompose the effects of external impulses, singling out state, industrial and general shocks, as well as idiosyncrasy (hypersensitivity) (Norrbin and Schlagenhauf 1996) factors, supply and demand shocks (Černíková 2010). The methodological basis for the decomposition of the impact of economic shocks goes back to the works of Blanchard and Quah (1989).

Studies on various aspects of an economic system's (of a country or a region) response to shocks, with differentiation of the nature and source of an impulse, the reaction speed, as well as the factors of sensitivity to shocks and various aspects of a system's resistance to shocks represent a vast area of research. An analysis of the impact of demand shocks on various EU countries (Černíková 2010) revealed both positive and negative influences. Moreover, against the background of the asymmetry of price reactions, the economies under analysis showed a nearly identical rate of response to shocks. An econometric analysis of the impact of shocks on the regions of Greece (Petrakos and Sycharis 2016) revealed an increase in regional inequalities. It is necessary to point out that developed export-oriented regions better adapted to the economic crisis, and solid integration with the EU market did not improve the regional indicators.

The assessment of the impact of shocks on the level of the national economy, including shocks caused by external factors, requires a wide range of diverse instruments for analysis, the most popular of which is the vector autoregression method (Crescenzi et al. 2016; Pesaran et al. 2003; Vorontsovsky et al. 2013). Based on the model designed, the authors of the study draw conclusions about the changes in the dynamics of the economic parameters. The results of the research of Pesaran et al. (2003) and Vorontsovsky et al. (2013) show that the consequences of a shock impact can be long-term or short-term, termed as persistence or non-persistence in development. Persistence of a shock is defined as a 'break point' of an economic system's development trend. The evolution of methods for estimating the stochastic factors in the process of macroeconomic modeling is represented in detail in the research of Vorontsovsky and Dmitriev (2014). Bristow and Healy (2015) point to the importance of time in the process of ensuring the sustainability of a regional economy, using the example of Wales. They argue that short-term adaptation to shocks does not guarantee long-term sustainability in the future.

Crescenzi et al. (2016) broaden the concept of an economy's susceptibility to external shocks. The authors argue that there is a relationship between the effects of shocks and the factors of an economy's vulnerability. The research of Briguglio et al. (2009) presents a wide range of factors that increase vulnerability. They include trade openness, export specialization, dependence on imports, access to the sea, poor ecology, the size of an economy, institutional weakness, and a lack of inbuilt stabilizers. Based on the analysis of the impact of the economic crisis during 2008-2009 on the regions of Poland, Marsik (2014) revealed specific factors in each region, capable of strengthening or neutralizing the effect of a shock. Later, the author conducted a study of eight regions from different European countries and proved the importance of the diversification of the economy and human capital in the process of ensuring stability to shocks (Marsik 2016).

Based on the US data, Crone (2005) and Beckworth (2010) revealed multi-directionality of the impact of monetary shocks on various regions and placed an emphasis on the asymmetry of the response of the 'energy zone' (groups of states exporting energy resources). Using the VAR (or vector autoregression) and SVAR (or structural vector autoregression models, the scholars obtained comparable results. A study based on the VAR model was conducted across groups 
of states united by peculiarities of economic cycles. The study led to the conclusion that the monetary policy of states that export energy resources is less sensitive to shocks (Crone 2005). Using the example of the impact of oil shocks on various states, Engermann (2014) observed spatial asymmetry - an atypical reaction of several states to negative shocks when the rest of the regions are insensitive.

The implementation of the VAR model on the example of Australia (Owyang and Wall 2009) showed that the regional response on monetary shocks is determined by three channels of shock distribution. Moreover, the intensity of the recession depends on the concentration of the banking sector in the region, while the size of the recession depends on the peculiarities of the regional industry. Fraser, MacDonald and Mullineux (2012) used the structural vector autoregressive SVAR model to show that regions differ in their response to a monetary shock: most regions have a response similar to changes in nationwide parameters; states in Western Australia and Queensland are more sensitive, which is associated with the low diversification of their economy (the mineral and raw material specialization).

Using the example of East Asian countries, the structural model of VAR with block exogeneity (SVARX) (Allegret, Couharde, Guillaumin 2012) made it possible to evaluate the comparative impact of each shock type on the internal variables of these countries, showing the priority significance of real shocks in comparison with nominal ones. The analysis of the impulse response shows that East Asian countries are more sensitive to the trading than monetary channel.

The use of dynamic stochastic general equilibrium models (DSGE models) in the study of regional response to external shocks is quite a difficult task since the openness of flows within a region (compared to the country level) complicates the modeling of the regional economic system. Although DSGE models allow investigating impulse response functions, they still have limitations. The results of a study of the influence of external and internal shocks on the regional indicators of the Sverdlovsk Oblast in Russia (Serkov 2018) can be quite useful in the management of regional development. It is necessary to point out that the model does not take into account the mutual influence of regions. The mechanisms of this influence are analyzed, for example, in the work of Tamegawa (2012), who proposes a single model for two regions.

A number of researchers attempted to transfer the assessment of the impact of shocks to the meso and micro levels. Thus, using the example of Norwegian peripheral regions, Salamonsen (2015) conducted a multilevel analysis of the impact of an exogenous shock on development processes at the macro and micro levels. The researcher revealed a strong and, interestingly, positive impact of an oil shock on the peripheral municipality, despite the noncontiguousness of institutional structures and signs of regional inequalities. Moreover, the researcher suggested that it is the influence of external shocks that allows overcoming regional inequalities.

Russian research includes the search for the indicators of sustainability of regional development (Ochkin 2018). A number of Russian studies focus on the impact of financial, price (Pilipenko 2015) and demand shocks on the sustainability and balance of the development of economic systems, as well as the issues of shock transfer among countries (Burlachkov and Golovnin 2014) and various responses of countries to global challenges. Bakhtizin, Buchwald, Kolchugin (2017) showed the relationship between the level of differentiation and the cyclical nature of economic development in regions. The indicator of the economy's spatial heterogeneity increases during the recovery phase and decreases during a crisis. Given that the vector of a country's regional development policy focuses on reducing economic differentiation, studies on the impact of shocks are of great practical value.

\section{Methods and Data}

The research methodology includes three components of analysis.

1. The formulation of an indicator of changes in institutional rules, which aggregates and quantitatively generalizes changes in standard and non-standard measures that have changed for the country, taking into account the structure of the trade and economy of the region.

The regional index of trade restrictions (or RITR) is proposed as an indicator (Danilova and Zimmerman 2014). This index was calculated with regard to an indicator of tariff and non-tariff protection level,which is applied by the country to its trading partners, i.e. general trade restriction index (or OTRI).

The conversion of a country's general trade restrictions index into regional indices is based on the difference in trade policies for each region. Regional differentiation depends on the import volume and structure, as well as on the regional sectoral diversification. The RITR calculation formula for the $i$-region is:

$$
\operatorname{RITR}_{i}=\frac{s_{a i} O T R I_{a}+s_{m i} O T R I_{m}}{s_{a i}+s_{m i}} \times D_{i}
$$

$O T R I_{a}$ - agricultural trade restriction index and $O T R I_{m}$ - industrial trade restriction index;

$s_{a i}$ - share of agricultural imports in the $i$-region;

$s_{m i}$ - share of industrial imports in the $i$-region;

$D_{i}$ - variance of specialization coefficient values. The specialization coefficient $(K d)$ is defined as the ratio of $r$-industry production in the $i$-region to the share of this industry in the country's economy. The greater the value of the $r$-industry specialization coefficient by the $i$-region, the average value of the 
industry specialization coefficient by the $i$-region, the higher the dispersion value and higher the level of trade barriers for the region are. The regional index of trade restrictions can serve as a tool for monitoring foreign trade policy programs.

Based on the volatility of the RITR value, it is possible to trace changes in trade rules for individual regions and, accordingly, estimate the intensity of the incoming shock impact on the economy.

2. The classification of regions by susceptibility, depending on the quality of persistence. The Hurst index (Hurst et al. 1965) was calculated based on the standardized range (R/ $\sigma$-analysis) for each region and four analyzed time periods. The method is presented on the example of one of the periods (2000-2012):

a) The average GRP ( $x$ ) growth rates value for a sample of length $\mathrm{N}$; for 2000-2012, $\mathrm{N}$ is equal to 13 . Definition of the average value requires the allocation of sub-periods: I - 2000-2012, II - 20012012 , ..., XII - 2011-2012, and calculation of the average GRP growth rate for each sub-period:

$\bar{x}_{I}=\frac{x_{2000}+\cdots+x_{2012}}{12}, \bar{x}_{I I}=\frac{x_{2001}+\cdots+x_{2012}}{11}, \ldots, \bar{x}_{X I I}=\frac{x_{2011}+x_{2012}}{2}$

Where $x_{2000}, \ldots, x_{2012}$ is the GRP growth rate value for $2000, \ldots, 2012$.

b) For calculating the standardized range, the deviations of the GRP growth rates from the average value for each sub-period 200-2012 are determined:

$$
\begin{aligned}
& Z_{I .2000}=x_{2000}-\bar{x}_{I}, \ldots, z_{I .2012}=x_{2012}-\bar{x}_{I} \\
& Z_{I I .2001}=x_{2001}-\bar{x}_{I I}, \ldots, Z_{I I .2012}=x_{2012}-\bar{x}_{I I} \\
& \ldots \\
& Z_{X I I .2011}=x_{2011}-\bar{x}_{I}, \ldots, Z_{X I I .2012}=x_{2012}-\bar{x}_{X I I}
\end{aligned}
$$

c) The deviation range for each sub-period is calculated on the basis of the maximum and minimum values for the region concerning the sub-period analyzed:

$$
\begin{aligned}
& R_{I}=\max (Z I .2000 ; \ldots ; Z I .2012)-\min (Z I .2000 ; \ldots ; Z I .2012) \\
& R_{I I}=\max \left(Z I I .2001 ; \ldots ; Z_{I I .2012}\right)-\min (Z I I .2001 ; \ldots ; Z I I .2012) \\
& \ldots \\
& R_{X I I}=\max \left(Z X I I .2011 ; \ldots ; Z_{X I I .2012)}-\min (Z X I I .2011 ; \ldots ; \text { ZXII.2012) }\right.
\end{aligned}
$$

Where $\max \left(z_{I .2000} ; \ldots ; z_{1.2012}\right), \max \left(z_{I I .2001} ; \ldots ;\right.$ $\left.z_{I I .2012}\right), \ldots, \max \left(z_{X I I .2011} ; \ldots ; z_{X I I .2012}\right)$ - the maximum value of the deviation from the average value for the subperiods I, II, ..., XII; $\min \left(z_{I .2000} ; \ldots ; z_{I .2012}\right), \min (-$ $\left.z_{I I .2001} ; \ldots ; z_{I I .2012}\right), \ldots, \min \left(z_{X I I .2011} ; \ldots ; z_{X I I .2012}\right)$ - the minimum value of the deviation from the average for the subperiods I, II, ..., XII;

e) The standard deviation $(\sigma)$ is determined for each sub-period:

$$
\begin{aligned}
& \sigma_{I}=\sqrt{\frac{\left(z_{I .2000}+\cdots+z_{I .2012}\right)^{2}}{12}, \sigma_{I I}}=\sqrt{\frac{\left(z_{I I .2001}+\cdots+z_{I I .2012}\right)^{2}}{11}}, \\
& \ldots, \sigma_{X I I}=\sqrt{\frac{\left(z_{X I I .2011}+z_{X I I .2012}\right)^{2}}{2}}
\end{aligned}
$$

d) The final Hurst $(\mathrm{H})$ indicator value in general terms is defined as:

$$
\frac{R}{\sigma}=c N^{H},
$$

where $\mathrm{R}$ is the $\operatorname{set}\left(R_{I}, R_{I I}, \ldots, R_{X I I}\right) ; \sigma$ is the set $\left(\sigma_{I}, \sigma_{I I}\right.$, ..., $\left.\sigma_{X I I}\right)$; $\mathrm{c}$ is a constant.

After bringing the equation to a linear form, the Hurst index $(\mathrm{H})$ for a sample of length $\mathrm{N}$ is defined as the regression coefficient (the regression line inclination angle):

$$
\ln \left(\frac{R}{\sigma}\right)=\ln (c)+H \ln (N)
$$

Interpretation of the Hurst exponent values (Table 1).

3) The identification of vulnerability factors for susceptible regions. The authors of the article identified a number of coefficients that allow quantitative representation of vulnerability factors in terms of resonance to a shock, namely:

a) the diversification level of sectoral structure is estimated with regard to the specialization economy coefficient of the $i$-region $\left(K_{d}\right)$;

b) the level of foreign trade openness is determined by the following indicators such as export the specialization coefficient (or Cex.spec,\%) as the export ratio of the $i$-region to the country's export; share of GRP imports $\left(d_{G R P}^{I M}\right)$ as the imports percentage of the $i$-region to GRP; the export-import ratio (or Rex/imp) as a ratio of the export volume of the $i$-region to import;

Tab. 1 Interval scale for the Hurst exponent.

\begin{tabular}{|l|l|l|l|}
\hline Value & Characteristics & Classical interpretation & Adapted interval scale \\
$0 \leq H<0.5$ & $\begin{array}{l}\text { Non- } \\
\text { persistence }\end{array}$ & 'Return to the average' situation & $\begin{array}{l}\text { The impact has the effect of short memory, which is } \\
\text { eventually neutralized in the context of a time range. } \\
\text { This means that the region's economy is insusceptible. }\end{array}$ \\
\hline$H=0.5$ & $\begin{array}{l}\text { Random } \\
\text { series }\end{array}$ & $\begin{array}{l}\text { This implies the presence of white noise, i.e. fulfillment of } \\
\text { some independent, random process. All the events are not } \\
\text { correlated. }\end{array}$ & $\begin{array}{l}\text { Implies an independent random process, for which } \\
\text { the impact of a shock is not determined. }\end{array}$ \\
\hline $0.5<H \leq 1$ & Persistence & $\begin{array}{l}\text { Offset stochastic volatility. The closer } \mathrm{N} \text { is to } 0.5, \text { the more } \\
\text { noisy noisier the range is and the less pronounced is its trend. }\end{array}$ & $\begin{array}{l}\text { Potential to maintain a long-term impact on a time } \\
\text { range; an environment susceptible to shocks. }\end{array}$ \\
\hline
\end{tabular}


c) investment related activity, i.e. foreign direct investment share (or FDI) of the $i$-region in the country's FDI $\left(\mathrm{C}_{\mathrm{FDI}}\right)$ as the ratio of the FDI of the $i$-region to the FDI of the country; foreign direct investment share in gross investment of the region $\left(d_{\sum I}^{F D I}\right)$ as the ratio of FDI to the main investment of the $i$-region.

The influence of resonance factors on the susceptibility of regions is estimated by the Vulnerability Index, which is defined as the weighted average of the three most important variable factors: the coefficient of export specialization, the coefficient of the import quota, and the coefficient of foreign direct investment (see Formula 6).

$$
I=\sum_{j=1}^{3} w_{j} \bar{k}_{j}
$$

Where $w_{j}$ is the weight of each of the factors; it is calculated on the basis of the paired correlation coefficients between the Hurst index $(\mathrm{H})$ and each of the three explanatory factors $j$ (see formula 7):

$$
w_{j}=\frac{\operatorname{cor}_{j_{H}}}{\sum_{j=1}^{3} \operatorname{cor}_{j H}}
$$

$\operatorname{cor}_{j_{H}}$ - the value of the coefficient of correlation between the $j$-th explanatory factor and the Hurst index $(\mathrm{H})$;

$\sum_{j=1}^{3} \operatorname{cor}_{j H}$ - the sum of the values of the coefficient of correlation between the indicators of export specialization, import quotas, foreign direct investment, on the one hand, and the Hurst index, on the other.

$\bar{k}_{j}$ - the average value for each of the factors $(j)$ by regions for the analyzed period.

For comparison purposes, the vulnerability index is defined separately for the group of restrictedly susceptible regions (19) and for the group of unresponsive regions (19) for the period of 2000-2012.

A change in the composite indicator of the Vulnerability Index allows estimating the intensity of the impact of trade and investment flows on the degree of regions' susceptibility to trade shocks and the sustainability of regional development.

Data. The study was conducted based on the data of 80 regions of Russia. The annual statistics of Rosstat for 2009-2015 was used to calculate indicators of the trade and investment channels.

The time series for calculating the Hurst index correspond to the GRP annual growth rate, which is the minimum period published by official statistics by region. The Hurst index was determined for four time periods $(2000-2009,2000-2012,2000-2014$, 2000-2015), which is explained by the need to assess the intermediate effects of external institutional shocks: the accession of Russia to the WTO, the creation of integration and the reduction of trade barriers (2009-2012); the introduction of restrictive sanctions and "antisanctions" (2013-2015).

Data (2000-2012) were used to estimate the vulnerability index, which is explained by the change of the methodology for calculating the foreign direct investment by the Central Bank of Russia in 2014 and the format of data by regions, which excluded the possibility to use the comparable calculations without modifying the indicator.

\section{Results}

The assessment of the regional index of trade restrictions for the years of 2009 and 2012, which correspond to the initial dates of drastic changes in the institutional rules, confirmed that the shock of trade liberalization led to a decrease in trade barriers due to the formation of the Customs Union and the preparation for accession to the WTO (Table 2). The RITR decreased from $11.75 \%$ to $7.98 \%$ (at the mean across the block of regions); the breakdown of regions in terms of the average value reflects the fact that $2 / 3$ of the regions are in the zone of low trade barriers (RITR is below average).

Tab. 2 Fragment of data on the regional index of trade restrictions, \%*.

\begin{tabular}{|l|c|c|l|r|r|}
\hline Vologda Oblast & 2009 & 2012 & & 2009 & 2012 \\
\hline Kaluga Oblast & 3.53 & 1.46 & Republic of Karelia & 10.46 & 12.50 \\
\hline Vladimir Oblast & 3.62 & 2.10 & $\begin{array}{l}\text { Jewish Auto- } \\
\text { nomous Oblast }\end{array}$ & 11.45 & 9.29 \\
\hline Chuvash Republic & 3.92 & 1.35 & $\begin{array}{l}\text { South Ossetia- } \\
\text { Alania }\end{array}$ & 14.38 & 12.87 \\
\hline Udmurt Republic & 4.24 & 1.26 & Chechen Republic & 16.85 & 16.63 \\
\hline Tver Oblast & 4.50 & 2.01 & Tymen Oblast & 19.92 & 5.67 \\
\hline St. Petersburg & 4.52 & 2.57 & Arkhangelsk Oblast & 20.40 & 13.22 \\
\hline Smolensk Oblast & 4.57 & 3.70 & Kaliningrad Oblast & 21.08 & 16.92 \\
\hline Voronezh Oblast & 4.63 & 4.31 & $\begin{array}{l}\text { Republic of } \\
\text { Ingushetia }\end{array}$ & 21.47 & 8.14 \\
\hline Leningrad Oblast & 4.71 & 3.77 & $\begin{array}{l}\text { Chukotka Auto- } \\
\text { nomous Okrug }\end{array}$ & 23.03 & 14.29 \\
\hline Moscow & 7.34 & 2.95 & $\begin{array}{l}\text { Republic of } \\
\text { Dagestan }\end{array}$ & 23.70 & 49.91 \\
\hline Republic of Sakha & 9.23 & 6.17 & Republic of Altai & 28.17 & 11.38 \\
\hline Orenburg Oblast & 10.92 & 3.44 & Republic of Kalmykia & 41.09 & 21.30 \\
\hline & & & Average regional & 11.57 & 7.98 \\
\hline
\end{tabular}

Source: Authors' calculations using OTRI data (World Bank 2013)

As a result of the trade liberalization shock, changes in the 'input parameter' are ambiguous. The institutional shock led to a decrease in the RITR in the group of regions with low trade barriers by $50 \%$ and to an increase in a number of regions by more than $100 \%$. The group of regions with high barriers included agrarian regions or regions that specialize in the fishing industry (the Arkhangelsk Oblast, the Kamchatka Krai, etc.). These sectors are the most protected sectors by countries even when there is an overall increase in openness. The second shock event was 
Tab. 3 Values of the Hurst coefficient for all periods under analysis.

\begin{tabular}{|c|c|c|c|c|c|c|c|c|c|}
\hline \multirow[b]{2}{*}{ Region } & \multicolumn{4}{|c|}{ H } & \multirow[b]{2}{*}{ Region } & \multicolumn{4}{|c|}{ H } \\
\hline & $\begin{array}{l}2000- \\
2009\end{array}$ & $\begin{array}{l}2000- \\
2012\end{array}$ & $\begin{array}{l}2000- \\
2014\end{array}$ & $\begin{array}{c}2000- \\
2015\end{array}$ & & $\begin{array}{c}2000- \\
2009\end{array}$ & $\begin{array}{l}2000- \\
2012\end{array}$ & $\begin{array}{l}2000- \\
2014\end{array}$ & $\begin{array}{l}2000- \\
2015\end{array}$ \\
\hline Kamchatka Krai & 0.3202 & 0.3403 & 0.2799 & 0.3692 & Tyumen Oblast & 0.5757 & 0.5030 & 0.2842 & 0.3728 \\
\hline Krasnodar Krai & 0.5345 & 0.3795 & 0.2834 & 0.3752 & Oryol Oblast & 0.6148 & 0.5057 & 0.2289 & 0.3373 \\
\hline Tyva Republic & 0.4587 & 0.3883 & 0.2385 & 0.3757 & Samara Region & 0.5424 & 0.5133 & 0.2716 & 0.3590 \\
\hline Republic of Dagestan & 0.4016 & 0.3942 & 0.269 & 0.3383 & Orenburg Oblast & 0.5151 & 0.5195 & 0.2235 & 0.3387 \\
\hline Belgorod Oblast & 0.4190 & 0.3967 & 0.2092 & 0.3546 & Kostroma Oblast & 0.5393 & 0.5220 & 0.1871 & 0.2996 \\
\hline Omsk Oblast & 0.6019 & 0.4029 & 0.2653 & 0.3691 & Kirov Oblast & 0.5453 & 0.5236 & 0.2526 & 0.3851 \\
\hline $\begin{array}{l}\text { Chukotka Autonomous } \\
\text { Okrug }\end{array}$ & 0.5185 & 0.4063 & 0.2151 & 0.2769 & Primorsky Krai & 0.4892 & 0.5236 & 0.2734 & 0.3383 \\
\hline North Ossetia-Alania & 0.4268 & 0.4078 & 0.2589 & 0.3845 & Lipetsk Oblast & 0.5368 & 0.5239 & 0.2590 & 0.3499 \\
\hline Kabardino-Balkaria & 0.4274 & 0.4185 & 0.3326 & 0.3755 & Vologda Oblast & 0.5615 & 0.5270 & 0.2951 & 0.3185 \\
\hline Magadan Oblast & 0.5538 & 0.4188 & 0.2766 & 0.3609 & Smolensk Oblast & 0.5612 & 0.5290 & 0.2847 & 0.3759 \\
\hline Republic of Adygea & 0.4611 & 0.4203 & 0.2663 & 0.3861 & Yaroslavl Oblast & 0.5354 & 0.5313 & 0.3174 & 0.3811 \\
\hline Kurgansk Oblast & 0.5571 & 0.4290 & 0.2202 & 0.2781 & Nizhny Novgorod Oblast & 0.5375 & 0.5340 & 0.2013 & 0.3084 \\
\hline Kemerevo Oblast & 0.4970 & 0.4295 & 0.2140 & 0.3149 & Astrakhan Oblast & 0.5815 & 0.5342 & 0.3197 & 0.3975 \\
\hline Zabaykalsky Krai & 0.4701 & 0.4309 & 0.2591 & 0.3003 & Ryazan Oblast & 0.5668 & 0.5354 & 0.2226 & 0.3493 \\
\hline Mari El Republic & 0.4418 & 0.4320 & 0.2390 & 0.3491 & Murmansk Oblast & 0.5417 & 0.5359 & 0.3001 & 0.3761 \\
\hline Arkhangelsk Oblast & 0.5216 & 0.4344 & 0.2757 & 0.3854 & Rostov Oblast & 0.5670 & 0.5371 & 0.3053 & 0.3151 \\
\hline Altai Republic & 0.5221 & 0.4347 & 0.3132 & 0.3543 & Republic of Ingushetia & 0.5410 & 0.5378 & 0.3096 & 0.3998 \\
\hline Voronezh Oblast & 0.4911 & 0.4380 & 0.2244 & 0.3450 & Tomsk Oblast & 0.4206 & 0.5380 & 0.2635 & 0.3624 \\
\hline $\begin{array}{l}\text { Karachay-Cherkess } \\
\text { Republic }\end{array}$ & 0.4321 & 0.4436 & 0.2359 & 0.3014 & Krasnoyarsk Krai & 0.3755 & 0.5382 & 0.2478 & 0.3281 \\
\hline $\begin{array}{l}\text { Republic of Sakha } \\
\text { (Yakutia) }\end{array}$ & 0.4963 & 0.4486 & 0.2718 & 0.3897 & Republic of Buryatia & 0.5550 & 0.5393 & 0.2301 & 0.3347 \\
\hline Komi Republic & 0.4740 & 0.4510 & 0.2104 & 0.2826 & Republic of Khakassia & 0.5263 & 0.5439 & 0.3138 & 0.4132 \\
\hline Irkutsk Oblast & 0.4897 & 0.4519 & 0.3043 & 0.3900 & Leningrad Oblast & 0.5482 & 0.5469 & 0.2903 & 0.3744 \\
\hline $\begin{array}{l}\text { Jewish Autonomous } \\
\text { Oblast }\end{array}$ & 0.5711 & 0.4532 & 0.2525 & 0.3181 & Kaluga Oblast & 0.6099 & 0.5530 & 0.2573 & 0.3451 \\
\hline Republic of Mordovia & 0.5005 & 0.4648 & 0.2454 & 0.3837 & Stavropol Krai & 0.6282 & 0.5547 & 0.2420 & 0.3623 \\
\hline Novgorod Oblast & 0.5108 & 0.4653 & 0.2413 & 0.3517 & Vladimir Oblast & 0.5690 & 0.5553 & 0.2219 & 0.3506 \\
\hline Pskov Oblast & 0.5113 & 0.4671 & 0.2494 & 0.3726 & Republic of Kalmykia & 0.5617 & 0.5563 & 0.2582 & 0.3385 \\
\hline Kursk Oblast & 0.4750 & 0.4676 & 0.2036 & 0.3543 & Volgograd Oblast & 0.5773 & 0.5572 & 0.2519 & 0.3185 \\
\hline Perm Krai & 0.4972 & 0.4686 & 0.2161 & 0.2921 & Tula Oblast & 0.5857 & 0.5591 & 0.2925 & 0.3773 \\
\hline Republic of Bashkortostan & 0.5023 & 0.4689 & 0.2468 & 0.3212 & Chuvash Republic & 0.5557 & 0.5599 & 0.1998 & 0.293 \\
\hline Tambov Oblast & 0.5253 & 0.4703 & 0.2967 & 0.4351 & Khabarovsk Krai & 0.5849 & 0.5646 & 0.348 & 0.4017 \\
\hline Amur Oblast & 0.5669 & 0.4828 & 0.3298 & 0.3609 & Chelyabinsk Oblast & 0.5490 & 0.5646 & 0.2203 & 0.3323 \\
\hline Saratov Oblast & 0.5867 & 0.4891 & 0.2896 & 0.3703 & Kaliningrad Oblast & 0.5529 & 0.5681 & 0.2249 & 0.3259 \\
\hline Sakhalinsk Oblast & 0.5677 & 0.4906 & 0.2676 & 0.418 & Republic of Tatarstan & 0.5616 & 0.5703 & 0.3157 & 0.3300 \\
\hline Sverdlov Oblast & 0.5184 & 0.4908 & 0.2861 & 0.3335 & Moscow Oblast & 0.5816 & 0.5754 & 0.1942 & 0.2831 \\
\hline Ivanovo Oblast & 0.5467 & 0.4910 & 0.2738 & 0.3797 & Udmurt Republic & 0.6033 & 0.5770 & 0.2850 & 0.4010 \\
\hline Republic of Karelia & 0.4786 & 0.4929 & 0.3004 & 0.3965 & Chechen Republic & 0.5547 & 0.5777 & 0.1503 & 0.3074 \\
\hline Ulyanovsk Oblast & 0.5310 & 0.4933 & 0.2323 & 0.3172 & St. Petersburg & 0.6251 & 0.5877 & 0.2227 & 0.3198 \\
\hline Tver Oblast & 0.5491 & 0.4948 & 0.2108 & 0.3105 & Penza Oblast & 0.5963 & 0.5903 & 0.2913 & 0.3896 \\
\hline Novosibirsk Oblast & 0.5373 & 0.4998 & 0.2779 & 0.2818 & Moscow & 0.6629 & 0.5990 & 0.2922 & 0.3727 \\
\hline \multirow[t]{2}{*}{ Altai Krai } & 0.5123 & 0.5004 & 0.2930 & 0.3657 & Bryansk Oblast & 0.6113 & 0.6116 & 0.2455 & 0.3621 \\
\hline & & & & & Average by region & 0.529419 & 0.497161 & 0.25964 & 0.350573 \\
\hline
\end{tabular}


due to sanctions and anti-sanctions in 2013-2015 and a sharp increase in restrictions.

Table 3 shows that in the first time period (20002009), the values of the Hurst coefficient in 37 regions are within the interval that indicates a potentially persistent type of economic development (the value is within the interval when the deviation of the time series from the previous growth trajectory is characterized by trend tolerance or the effect of long memory). Non-persistence was observed in 9 regions characterized by a return to the average and the effect of short memory. A random series was revealed only in 34 regions (a random process, for which the determination of the impact of an external shock is impossible).

The assessment of the period of 2000-2012 revealed the following facts: the Hurst coefficient in 42 constituent entities of Russia was within the interval of the non-persistent type of development, 19 regions demonstrated a random range, and 19 were characterized by persistence. This means that the liberalization of institutional rules and the reduction of import trade restrictions turned out to be 'unsafe' for 19 regions in terms of sustainability (a potential for persistent development was observed). The additional analysis of the period of 2000-2011 showed that in 11 out of 19 regions, the Hurst coefficient was not within the persistent interval, while the calculation that included the year of 2012 (the authors believe that this was triggered by a shock) revealed a drag of the Hurst coefficient in these regions into a zone that has the potential for long-term shock effects.

Tab 4 The Hurst exponent in the regions with a potential for persistent development $(2009,2011,2012)$.

\begin{tabular}{|l|c|c|c|}
\hline Leningrad Oblast & $2000-2009$ & $2000-2011$ & $2000-2012$ \\
\hline Kaluga Oblast & 0.5482 & 0.4382 & 0.5469 \\
\hline Republic of Tatarstan & 0.6099 & 0.5625 & 0.5530 \\
\hline Moscow & 0.5816 & 0.5298 & 0.5703 \\
\hline St. Petersburg & 0.6251 & 0.5368 & 0.5754 \\
\hline Moscow & 0.6629 & 0.6379 & 0.5990 \\
\hline Stavropol Krai & 0.6282 & 0.5912 & 0.5547 \\
\hline Vladimir Oblast & 0.5690 & 0.5084 & 0.5553 \\
\hline Volgograd Oblast & 0.5773 & 0.5502 & 0.5572 \\
\hline Tula Oblast & 0.5857 & 0.5278 & 0.5591 \\
\hline Chuvash Republic & 0.5557 & 0.5006 & 0.5599 \\
\hline Chelyabinsk Oblast & 0.5490 & 0.5907 & 0.5646 \\
\hline Udmurt Republic & 0.6033 & 0.6358 & 0.577 \\
\hline Penza Oblast & 0.5963 & 0.5761 & 0.5903 \\
\hline Bryansk Oblast & 0.6113 & 0.5951 & 0.6116 \\
\hline Kaliningrad Oblast & 0.5529 & 0.5335 & 0.5681 \\
\hline Khabarovsk Krai & 0.5849 & 0.5393 & 0.5646 \\
\hline Republic of Kalmykia & 0.5617 & 0.4947 & 0.5563 \\
\hline Chechen Republic & 0.5547 & 0.2702 & 0.5777 \\
\hline
\end{tabular}

In respect of eight regions, the authors of the study introduced a hypothesis about the stable maintenance of the situation with a high concentration of vulnerabilities. This is explained by the fact that in the initial analysis period of 2000-2009, these regions already belonged to the zone with the potential for persistence (highlighted in a grey background in Table 4).

During the estimation of the Hurst coefficient for the time interval of 2000-2014 and 2000-2015, no regions demonstrated a value typical of the persistent type of economic development. The decrease in the coefficient in the third of the periods under analysis (the period of foreign trade and economic restriction) in all constituent entities of Russia cannot be viewed as a transition of 19 regions susceptible to shocks to a fundamentally new state, i.e. as a shift of their status to susceptible. It is necessary to take into account the following arguments, which allowed attributing these regions to the zone of instability in the economy of Russia and defining them as 'partially susceptible': 1) the shock impulses under examination (from 2009 to 2012 and from 2012 to 2015) are multidirectional. The effect of liberalization (due to the accession to the WTO and the commencement of the transition period) is nearly neutralized by sanctions/ anti-sanctions; restriction came to replace liberalization, which could provoke a counter-turnabout of regional parameters (Table 5 shows the trade and economic parameters of the regions; multi-directionality is highlighted in a grey background); 2) the multidirectional dynamics of regional economic development in this period: the recovery growth of 2010-2011 was replaced by stagnant dynamics till 2013 and a drop in production in 2014. Changes in institutional rules 'knocked out' the regions of Russia from the path of progressive development, reduced economic activity, and led to a 'downshift' of the national production;

3) the 'break-up' in the development trajectory was manifested in the increase in the deviation of the GRP growth rate from the average value and the decrease in the Hurst coefficient. The high volatility and the sharp recession in 2013-2014 affected the growth of the mean square value deviation, which reduced the values of the Hurst coefficient. Comparison of the indices for the limited susceptible regions with insensitive and average data for regions of Russia allows the factors identifying the limited susceptible regions to distinguish (Table 5), namely a high level of openness of the economy (for example, 2014. The export specialization coefficient of partially susceptible regions is $3.22 \%$, on average $-1.2 \%$; the import quota value, respectively, was $26.89 \%$ and $12.57 \%$; RITR $-5.02 \%$ and $7.99 \%$ in 2012). The high susceptibility is explained, accordingly, by the fact that the regions are sensitive to the destabilizing effect of changing the rules governing both export and import operations. This should be added to the high level of localization of foreign investment in 


\begin{tabular}{|c|c|c|c|c|c|c|c|c|c|c|c|c|c|c|c|c|c|c|c|}
\hline & ZTOZ & $\begin{array}{l}\stackrel{R}{0} \\
\infty\end{array}$ & $\begin{array}{l}\stackrel{0}{1} \\
\stackrel{9}{9}\end{array}$ & $\stackrel{\infty}{\sim}$ & $\begin{array}{l}\stackrel{\infty}{\infty} \\
\stackrel{n}{n}\end{array}$ & 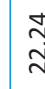 & & o. & $\vec{m}$ & $\begin{array}{l}8 \\
\stackrel{\leftrightarrow}{\circ} \\
\text { - }\end{array}$ & $\underset{\rightarrow}{\hat{m}}$ & 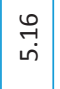 & 点 & $\begin{array}{l}\infty \\
\stackrel{\infty}{0} \\
0 \\
0\end{array}$ & 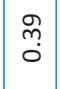 & $\stackrel{\substack{0 \\
0}}{0}$ & 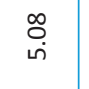 & 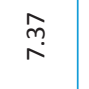 & $\stackrel{\infty}{\stackrel{\infty}{+}}$ \\
\hline & 6002 & 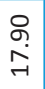 & ڤึ & $\begin{array}{l}\stackrel{g}{G} \\
\text { G }\end{array}$ & $\underset{i}{\stackrel{p}{i}}$ & $\begin{array}{l}a \\
\infty \\
\beth\end{array}$ & & $\vec{J}$ & $\stackrel{\widetilde{N}}{\circ}$ & $\begin{array}{l}\overrightarrow{0} \\
\dot{\vec{g}}\end{array}$ & $\begin{array}{l}\stackrel{9}{7} \\
\stackrel{f}{7}\end{array}$ & 竎 & 文 & $\underset{i}{\stackrel{O}{i}}$ & $\begin{array}{l}\hat{O} \\
\dot{\sigma}\end{array}$ & 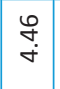 & નુ & 莡 & $\underset{\sim}{\tilde{f}}$ \\
\hline & ZTOZ & 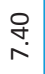 & $\stackrel{\infty}{\stackrel{\infty}{i n}}$ & 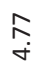 & 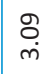 & $\begin{array}{l}\bar{b} \\
m\end{array}$ & & o. & $\begin{array}{l}\vec{f} \\
0 \\
0\end{array}$ & $\stackrel{m}{\rightarrow}$ & ?े & $\begin{array}{l}\tilde{O} \\
0 \\
0\end{array}$ & $\begin{array}{l}0 \\
0 \\
0\end{array}$ & ָ̊. & $\begin{array}{l}0 \\
0 \\
0\end{array}$ & $\begin{array}{l}m \\
0 \\
0\end{array}$ & $\stackrel{n}{i}$ & $\underset{\infty}{\infty}$ & 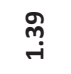 \\
\hline & $600 z$ & $\begin{array}{l}\stackrel{g}{q} \\
\dot{g}\end{array}$ & $\underset{i}{\stackrel{7}{i}}$ & 岇 & i & $\underset{m}{m}$ & & $\begin{array}{c}m \\
\stackrel{m}{0} \\
\end{array}$ & Oֶ̊ & $\underset{\rightarrow}{\stackrel{m}{-}}$ & $\stackrel{\text { f }}{\rightarrow}$ & $\begin{array}{l}\tilde{\delta} \\
\dot{0}\end{array}$ & $\stackrel{\vec{T}}{\overrightarrow{0}}$ & $\begin{array}{c}0 \\
\tilde{o} \\
0\end{array}$ & ָָ & $\begin{array}{c}0 \\
\tilde{o} \\
0\end{array}$ & $\stackrel{n}{n}$ & $\begin{array}{l}\infty \\
\infty \\
0\end{array}$ & $\underset{\text { i }}{\stackrel{0}{ }}$ \\
\hline \multirow{5}{*}{$\therefore$} & & $\rightarrow$ & $\rightarrow$ & $\rightarrow$ & $\leftarrow$ & $\rightarrow$ & & $\rightarrow$ & $\rightarrow$ & $\leftarrow$ & $\rightarrow$ & $\leftarrow$ & $\rightarrow$ & $\leftarrow$ & $\rightarrow$ & $\leftarrow$ & $\leftarrow$ & $\rightarrow$ & $\leftarrow$ \\
\hline & tI0Z & 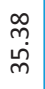 & $\underset{\sim}{\stackrel{\sim}{\sim}}$ & $\begin{array}{l}\tilde{O} \\
\dot{f}\end{array}$ & ஸ̂̀ & $\begin{array}{l}8 \\
0 \\
0 \\
0\end{array}$ & & $\begin{array}{c}\tilde{\sigma} \\
\text { స. }\end{array}$ & $\stackrel{\substack{\infty \\
\sim}}{\sim}$ & $\begin{array}{c}\underset{g}{+} \\
\underset{\rightarrow}{\infty}\end{array}$ & 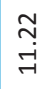 & $\begin{array}{c}\tilde{m} \\
\sigma \\
\end{array}$ & $\begin{array}{l}\tilde{n} \\
\stackrel{n}{0} \\
\end{array}$ & $\begin{array}{l}\infty \\
\stackrel{7}{6} \\
0\end{array}$ & 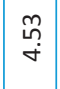 & $\begin{array}{l}\mathscr{O} \\
\dot{f}\end{array}$ & $\begin{array}{l}\stackrel{\circ}{\infty} \\
\stackrel{\sim}{\oplus}\end{array}$ & 站 & $\begin{array}{l}\stackrel{n}{n} \\
\stackrel{N}{N}\end{array}$ \\
\hline & & $\leftarrow$ & $\rightarrow$ & $\leftarrow$ & $\leftarrow$ & $\leftarrow$ & & $\leftarrow$ & $\leftarrow$ & $\leftarrow$ & $\leftarrow$ & $\leftarrow$ & $\rightarrow$ & $\leftarrow$ & $\leftarrow$ & $\leftarrow$ & $\leftarrow$ & $<$ & $\leftarrow$ \\
\hline & ZTOE & $\begin{array}{l}\infty \\
\dot{y} \\
\dot{\gamma}\end{array}$ & $\underset{\stackrel{\sim}{\sim}}{\stackrel{\sim}{\sim}}$ & $\begin{array}{l}\text { 芦 } \\
\text { gे }\end{array}$ & $\stackrel{\infty}{\stackrel{\infty}{~}}$ & $\begin{array}{l}\infty \\
m \\
\sigma \\
\sigma\end{array}$ & & 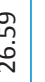 & $\begin{array}{l}\tilde{r} \\
\dot{r}\end{array}$ & $\begin{array}{l}\underset{N}{\tilde{G}} \\
\underline{\underline{G}}\end{array}$ & 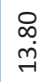 & 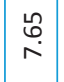 & \begin{tabular}{l}
0 \\
$\stackrel{7}{+}$ \\
\multirow{7}{*}{}
\end{tabular} & 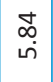 & 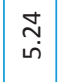 & $\underset{m}{\stackrel{N}{m}}$ & $\begin{array}{l}\text { d } \\
\stackrel{\leftrightarrow}{~}\end{array}$ & ִִ & 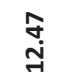 \\
\hline & $600 z$ & 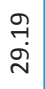 & $\begin{array}{l}\tilde{\delta} \\
\stackrel{\sim}{\sim}\end{array}$ & $\underset{\substack{\vec{f} \\
m}}{\vec{j}}$ & $\begin{array}{l}\stackrel{8}{0} \\
\stackrel{1}{*}\end{array}$ & $\frac{7}{6}$ & & 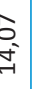 & 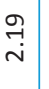 & 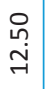 & 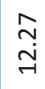 & $\begin{array}{l}\stackrel{\leftrightarrow}{\infty} \\
\stackrel{\infty}{\omega}\end{array}$ & 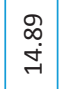 & $\begin{array}{l}\vec{\infty} \\
\dot{\sigma}\end{array}$ & $\begin{array}{l}O \\
\dot{m}\end{array}$ & $\begin{array}{l}\tilde{O} \\
\dot{N}\end{array}$ & సี & 胡 & 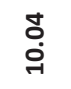 \\
\hline & & $\leftarrow$ & $\leftarrow$ & $\leftarrow$ & $\rightarrow$ & $\leftarrow$ & & $\leftarrow$ & $\rightarrow$ & $\leftarrow$ & $\leftarrow$ & $\rightarrow$ & $\leftarrow$ & $\rightarrow$ & $\leftarrow$ & $\rightarrow$ & $\rightarrow$ & 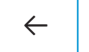 & $\leftarrow$ \\
\hline & †TOZ & 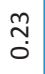 & $\vec{b}$ & 令 & $\stackrel{m}{f}$ & $\bar{c}$ & & స̃ & 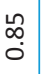 & $\begin{array}{l}\overrightarrow{0} \\
0 \\
0\end{array}$ & $\stackrel{\infty}{\stackrel{m}{m}}$ & $\underset{\substack{m \\
i}}{ }$ & 喿 & 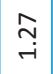 & 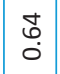 & 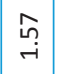 & $\underset{\sim}{\stackrel{\leftrightarrow}{\sim}}$ & $\stackrel{\infty}{\infty}$ & 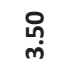 \\
\hline \multirow[t]{2}{*}{ 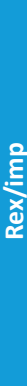 } & & $\rightarrow$ & $\leftarrow$ & $\rightarrow$ & $\rightarrow$ & $\leftarrow$ & & $\leftarrow$ & $\rightarrow$ & $\rightarrow$ & $\leftarrow$ & $\leftarrow$ & $\rightarrow$ & $\rightarrow$ & $\rightarrow$ & $\leftarrow$ & $\leftarrow$ & $\rightarrow$ & $\leftarrow$ \\
\hline & ZTOZ & 今ે & 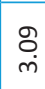 & 总 & ఫ్ & o & & 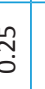 & 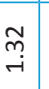 & 芯 & 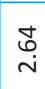 & $\stackrel{7}{\stackrel{9}{ }}$ & 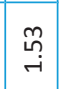 & $\underset{\sim}{\stackrel{T}{i}}$ & $\begin{array}{l}\stackrel{n}{n} \\
0 \\
0\end{array}$ & 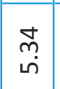 & $\underset{\substack{\infty\\
}}{2}$ & 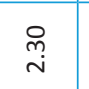 & $\stackrel{\text { Pे }}{m}$ \\
\hline & 6002 & $\tilde{O}$ & 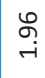 & $\begin{array}{l}\stackrel{n}{0} \\
0\end{array}$ & 뭉 & à & & \begin{tabular}{l}
$\infty$ \\
\hdashline \\
0 \\
0
\end{tabular} & 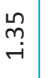 & $\hat{\circ}$ & 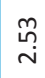 & $\begin{array}{l}0 \\
0 \\
\dot{i}\end{array}$ & 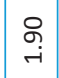 & $\stackrel{\vec{i}}{i}$ & $\underset{\sim}{\stackrel{\infty}{+}}$ & ŏ & 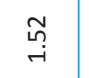 & & 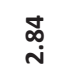 \\
\hline & & $\leftarrow$ & $\rightarrow$ & $\rightarrow$ & $\rightarrow$ & $\rightarrow$ & & $\rightarrow$ & $\rightarrow$ & $\leftarrow$ & $\leftarrow$ & $\rightarrow$ & $\rightarrow$ & $\leftarrow$ & $\rightarrow$ & $\rightarrow$ & $\rightarrow$ & $\rightarrow$ & $\leftarrow$ \\
\hline & troz & $\underset{-}{-}$ & $\underset{\dot{m}}{\stackrel{\leftrightarrow}{m}}$ & 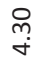 & $\underset{\sim}{\stackrel{g}{r}}$ & 7 & & o. & $\begin{array}{l}\Delta \\
\text { d. } \\
\end{array}$ & ণ़े & $\underset{0}{N}$ & $\mid \begin{array}{c}0 \\
0 \\
0\end{array}$ & 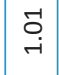 & $\begin{array}{l}\tilde{O} \\
0\end{array}$ & $\begin{array}{l}n \\
0 \\
0\end{array}$ & $\stackrel{\stackrel{n}{n}}{0}$ & $\underset{\sim}{\sim}$ & $\stackrel{m}{\tilde{O}}$ & 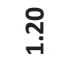 \\
\hline & & $\leftarrow$ & $\leftarrow$ & $\leftarrow$ & $\leftarrow$ & $\leftarrow$ & & $\leftarrow$ & $\leftarrow$ & $\rightarrow$ & $\leftarrow$ & $\leftarrow$ & $\rightarrow$ & $\rightarrow$ & $\rightarrow$ & $\leftarrow$ & $\leftarrow$ & $\rightarrow$ & $\rightarrow$ \\
\hline 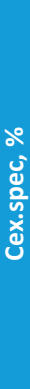 & Ztoz & 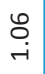 & $\stackrel{\infty}{\stackrel{m}{m}}$ & 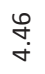 & 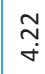 & $\frac{0}{7}$ & & 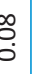 & $\begin{array}{l}\stackrel{8}{0} \\
\dot{0}\end{array}$ & $\stackrel{n}{0}$ & : & 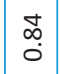 & $\underset{\sim}{\stackrel{7}{ت}}$ & 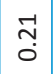 & $\mid \begin{array}{l}0 \\
0 \\
0\end{array}$ & $\vec{f}$ & $\stackrel{\substack{\infty \\
n}}{n}$ & 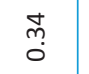 & 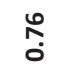 \\
\hline & 6002 & જ્ & 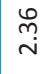 & 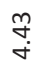 & 宲 & a & & o & $\begin{array}{l}\stackrel{n}{0} \\
0\end{array}$ & $\begin{array}{l}0 \\
\stackrel{0}{0}\end{array}$ & : & $\begin{array}{l}\hat{A} \\
\dot{0}\end{array}$ & 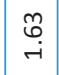 & $\begin{array}{c}0 \\
m \\
0\end{array}$ & $\begin{array}{l}\hat{o} \\
\dot{0}\end{array}$ & $\ddot{0}$ & $\underset{m}{\hat{m}}$ & $\stackrel{\substack{m \\
0}}{0}$ & $\stackrel{f}{-}$ \\
\hline \multirow{5}{*}{$\bar{z}$} & & $\rightarrow$ & $\rightarrow$ & $\rightarrow$ & $\rightarrow$ & $\rightarrow$ & & $\leftarrow$ & $\rightarrow$ & $\leftarrow$ & $\leftarrow$ & $\rightarrow$ & $\leftarrow$ & $\leftarrow$ & $\rightarrow$ & $\leftarrow$ & $\rightarrow$ & 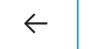 & $\rightarrow$ \\
\hline & tז0Z & $\begin{array}{l}\vec{\infty} \\
\stackrel{-1}{0} \\
0\end{array}$ & 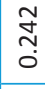 & $\begin{array}{l}\stackrel{0}{\stackrel{0}{0}} \\
\text { O. }\end{array}$ & $\begin{array}{c}0 \\
\stackrel{2}{0} \\
\stackrel{1}{0}\end{array}$ & 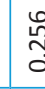 & & $\begin{array}{l}0 \\
0 \\
0 \\
0 \\
\end{array}$ & 离 $\underset{\substack{\infty \\
\hdashline}}{ }$ & $\begin{array}{l}\infty \\
\stackrel{\infty}{7} \\
0 \\
0\end{array}$ & $\begin{array}{l}\stackrel{\infty}{N} \\
0\end{array}$ & 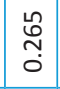 & 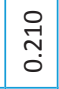 & 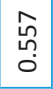 & 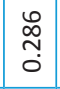 & $\underset{\substack{\infty \\
\sim \\
0}}{0}$ & $\begin{array}{l}0 \\
0 \\
0 \\
0\end{array}$ & $\underset{\rightarrow}{\stackrel{\vec{H}}{\text { I }}}$ & $\begin{array}{l}\vec{m} \\
\text { ô } \\
0\end{array}$ \\
\hline & & $\leftarrow$ & $\leftarrow$ & $\leftarrow$ & $\rightarrow$ & $\leftarrow$ & & $\rightarrow$ & $\leftarrow$ & $\rightarrow$ & $\rightarrow$ & $\leftarrow$ & $\rightarrow$ & $\leftarrow$ & $\leftarrow$ & $\rightarrow$ & $\leftarrow$ & $\leftarrow$ & $\leftarrow$ \\
\hline & Zт0乙 & \begin{tabular}{l}
$\stackrel{0}{\circ}$ \\
\hdashline \\
0
\end{tabular} & $\begin{array}{l}\hat{y} \\
\dot{o}\end{array}$ & 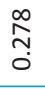 & 各 & $\begin{array}{l}\text { n} \\
\tilde{m} \\
0\end{array}$ & & 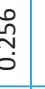 & $\begin{array}{c}\vec{m} \\
\stackrel{m}{0} \\
\dot{0}\end{array}$ & $\begin{array}{l}\hat{\sigma} \\
\stackrel{2}{0}\end{array}$ & $\begin{array}{l}\vec{\infty} \\
\overrightarrow{0}\end{array}$ & 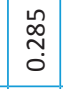 & ָ̃ & $\begin{array}{l}n \\
0 \\
0 \\
0\end{array}$ & $\begin{array}{l}\overrightarrow{1} \\
\tilde{m} \\
0\end{array}$ & 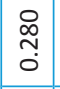 & $\begin{array}{l}\text { Oิ } \\
0\end{array}$ & & 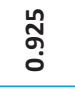 \\
\hline & 6002 & $\begin{array}{l}\stackrel{+}{t} \\
\stackrel{-}{0}\end{array}$ & $\begin{array}{l}\stackrel{\sim}{\infty} \\
\stackrel{0}{0}\end{array}$ & 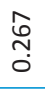 & $\begin{array}{l}\text { ô } \\
\text { on }\end{array}$ & $\stackrel{\mathfrak{n}}{0}$ & & 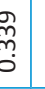 & 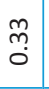 & $\begin{array}{l}\hat{0} \\
\text { Oे }\end{array}$ & Iิ & $\begin{array}{l}\tilde{N} \\
\tilde{N} \\
0\end{array}$ & $\begin{array}{l}\hat{\tilde{N}} \\
\stackrel{0}{0}\end{array}$ & 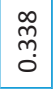 & 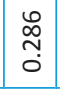 & 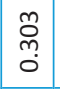 & 움 & & $\begin{array}{l}\infty \\
\stackrel{0}{0} \\
\stackrel{0}{0}\end{array}$ \\
\hline \multirow{2}{*}{$\begin{array}{l}\stackrel{2}{0} \\
\frac{c}{\tilde{E}}\end{array}$} & Ztoz & $\underset{\Im}{\hat{T}}$ & $\underset{\sim}{\stackrel{N}{m}}$ & $\stackrel{n}{n}$ & $\underset{\sim}{\stackrel{N}{-1}}$ & f & & 舁 & $\stackrel{7}{\sim}$ & $\stackrel{ }{\vec{i}}$ & $\underset{-}{\stackrel{\sim}{\sim}}$ & $\stackrel{?}{\stackrel{P}{i}}$ & $\stackrel{\varphi}{\rightarrow}$ & $\begin{array}{l}\infty \\
\stackrel{n}{n}\end{array}$ & 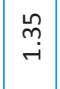 & 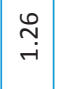 & ర్ర & 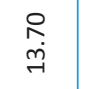 & $\stackrel{\text { g }}{\wedge}$ \\
\hline & $600 z$ & 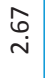 & ㄱ. & 垈 & $\begin{array}{l}\stackrel{\bullet}{\circ} \\
\dot{m}\end{array}$ & $\stackrel{n}{m}$ & & 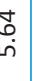 & $\begin{array}{l}\tilde{N} \\
\dot{\omega} \\
\text {. }\end{array}$ & $\begin{array}{l}\tilde{\sigma} \\
\dot{m}\end{array}$ & 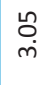 & ஸુ & $\begin{array}{l}\vec{f} \\
\dot{m}\end{array}$ & शุ. & $\begin{array}{l}\tilde{r} \\
\tilde{r}\end{array}$ & $\underset{\mathcal{f}}{\mathcal{Z}}$ & $\underset{\infty}{\stackrel{q}{q}}$ & $\underset{\stackrel{\infty}{\sim}}{\stackrel{\infty}{二}}$ & $\begin{array}{l}\text { nُ̂ } \\
\text { تn }\end{array}$ \\
\hline & อ̆ & 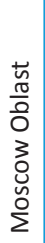 & 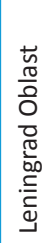 & 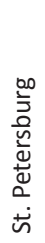 & 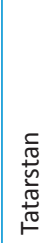 & 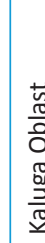 & & 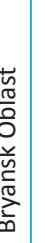 & 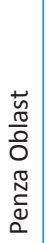 & 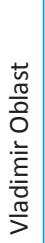 & $\begin{array}{l}\frac{\mathrm{n}}{\frac{\pi}{0}} \\
\frac{0}{0} \\
\frac{\pi}{5}\end{array}$ & 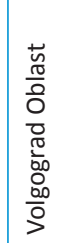 & 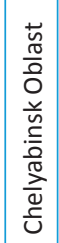 & 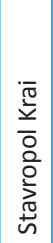 & 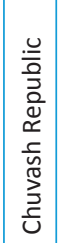 & 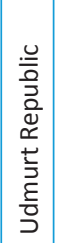 & 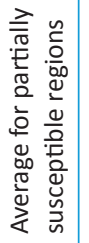 & 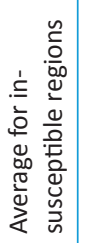 & 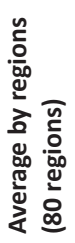 \\
\hline
\end{tabular}


Tab. 6 The Vulnerability Index of partially susceptible and insusceptible regions to external institutional shocks.

\begin{tabular}{|c|c|c|c|c|c|c|}
\hline \multirow{2}{*}{$\begin{array}{l}\text { Factors and } \\
\text { Vulnerability Index }\end{array}$} & \multicolumn{3}{|c|}{ Partially susceptible regions (19) } & \multicolumn{3}{|c|}{ Insusceptible regions (19) } \\
\hline & $\operatorname{cor}_{j H}$ & $\bar{k}$ & w & $\operatorname{cor}_{j H}$ & $\bar{k}$ & w \\
\hline Cex.spec. & 0.379 & 3.027 & 0.485 & -0.073 & 0.337 & 0.646 \\
\hline $\mathrm{d}_{G R P}^{\mathrm{IM}}$ & 0.072 & 26.524 & 0.092 & 0.039 & 6.998 & 0.345 \\
\hline $\mathrm{C}_{\mathrm{FDI}}$ & 0.330 & 3.199 & 0.423 & -0.001 & 0.927 & 0.009 \\
\hline I & \multicolumn{3}{|c|}{$I=5.261$} & \multicolumn{3}{|c|}{$I=2.640$} \\
\hline
\end{tabular}

the economy of partially susceptible regions: the indicator "regional share in the country's foreign direct investment" is $2.75 \%$, while the regional average is $1.39 \%$; the indicator "the share of foreign investments in the aggregate investments of the region" $5.08 \%$ and $4.78 \%$, respectively. High rates of foreign trade and foreign investment are good conductors of institutional shocks, especially with their simultaneous effects (as was observed in Russia), multiplying destabilizing effects and increase the likelihood of a change in the trend of regional development.

The implementation of a particular type of susceptibility in a region depends on the peculiarities of the economic environment in which the shock impulse occurs. Partially susceptible regions have a more vulnerable economy due to the concentration of factors of trade-economic and investment channels. The vulnerability index is 5.261 and higher than that of insusceptible regions (Table 6).

The high vulnerability of partially susceptible regions to the trade liberalization shock was due to a number of factors, such as the high trade openness manifested in the regions' export specialization (the coefficient of export specialization exceeds the average value of all regions five times) and the significant share of import in the GRP (the import quota is twice higher compared with other subjects of Russia), as well as in the high intensity of investment ties with the foreign sector due to the localization of the FDI in most partially susceptible regions (the coefficient of FDI is higher than the average for all regions).

\section{Discussion}

In the context of the impulse response approach, the authors of the article studied the effects of institutional shocks on 80 regions of Russia. To prove the hypothesis put forward, they relied on the concept of 'persistence' introduced by Pesaran et al. (2003) and Vorontsovsky et al. (2013). The research results are basically consistent with the analysis of the above-mentioned authors. Nevertheless, the parameters that are assessed and the instruments for our analysis are quite different from theirs. Analyzing the effect of an external shock on the national economy, Vorontsovsky et al. (2013) uses short-term statistics and builds a vector autoregression model based on it. In this article, we use the GPR annual values to estimate the Hurst exponent since no short-term statistics is available for the regions under analysis. As a matter of fact, the instruments used by the authors of this study are better adapted for assessing consequences at the regional level (simultaneously ensuring comparability at the country level) and allow proving the first part of the hypothesis concerning the differences in the level of susceptibility among regions.

We agree with the position of Masik (2014), who argues that each region is unique in terms of the factors whose concentration allows determining the final vulnerability or sustainability of the economy. Narrowing the range of vulnerability factors (Briguglio et al. 2009) in terms of trade-economic and investment channels, we proved the second part of the hypothesis, which implies that the differences in the consequences of an external influence among regions are due to a different set of economic factors. A susceptible environment is related to the concentration of vulnerability factors, such as the high level of foreign trade openness, as well as the high intensity of investment ties with the foreign sector. We propose a set of instruments for assessing the differential response of regions to institutional shocks. Compared to the results of studies on regional asymmetries of shock influences on the example of the United States (Crone 2005; Beckworth 2010), Australia (Owyang and Wall 2009; Fraser, MacDonald, Mullineux 2012), Norway (Salamonsen 2015), Greece (Petrakos and Sycharis 2016), and Great Britain (Bristow and Healy 2015), our approach not only records differences in the response of regional economic systems but also has a predictive potential. The quality of persistence/ non-persistence allows filtering out the resonant factors of a region's susceptibility to a shock and formulating a prolonged view of the vulnerability or sustainability of a region. The study confirms the second part of the hypothesis about the impact of the specifics of a regional economic system on the scale of shock consequences and the susceptibility of a region. For comparison, Vorontsovsky et al. (2016) propose to predict the response of a regional economic system to shocks by determining the time point when the development trend and 'turning points', while Bakhtizin, Buchwald, Kulchugin (2017) suggest to assess the perspectives of regional differentiation in terms of cyclical development. Conceptually, our approach does not contradict the above-mentioned studies. 
In addition, this study contributes three provisions to the scientific literature. First, the review of the theory of shocks and the analysis of current facts of economic development in Russia allows expanding the understanding of the spatial impact of external institutional shocks in the context of the socio-economic heterogeneity of federal countries and the economic openness. In particular, we have identified the institutional component of a shock, as well as the types of possible consequences of the expansion of external institutional shocks. Secondly, the main difference of our methodological approach includes the proposed index of the 'input' indicator of shock strikes - the regional index of trade restrictions (RITR), which accumulates the specific impact of shock changes in standard and non-standard measures on the regions (there is no such indicator for regions). Thirdly, the results allowed identifying 19 regions whose economies are very sensitive to shocks (partially susceptible). About $45 \%$ of the total GRP from all regions falls on the partially susceptible regions, i.e. they form an important territorial zone that is unstable to shocks. Consequently, there is an increase in the overall susceptibility of the country's economy to any institutional shocks in the sphere of foreign economic cooperation. Another contribution of the study is related to the identification of the institutional type of shocks.

\section{Conclusion}

We have proposed a methodological approach to assessing the impact of external institutional shocks and tested it relying on the 2009-2015 data. The results of the analysis allowed singling out 19 regions with limited susceptibility to external institutional shocks out of the analyzed 80 regions, which means that $23.8 \%$ of regions are potentially predisposed to an unstable state and a distruction of the development direction. Among these regions, the authors single out regions with a steady concentration of vulnerability factors (for example, the Chelyabinsk Oblast) and those that are distinguished by high openness to trade and/or investment channels. A highly important territorial zone of increased susceptibility and vulnerability can lead to significant economic and social consequences for the entire country. The proposed approach to assessing the susceptibility of regions has practical importance for public authorities since it provides a basis for choosing priority areas for improving sustainability, creating a system of diagnostics and stress testing of the regional economy in the context of identifying vulnerabilities to shock impulses.

The consistent implementation of the proposed methodological approach in the future will allow generating a sufficient database for a comparative assessment of the dynamics of the development of regions with non-persistent and persistent types of economic development, as well as assessing the cyclical nature of the response of a regional economic system to institutional shocks. Further studies may be related to the situation of the counter-turnabout of regional parameters. In addition, it is of scientific interest to study the mechanisms of the expansion and responsiveness of regional economic systems to institutional shocks.

\section{Acknowledgements}

The work was supported by Act 211 Government of the Russian Federation, contract No. 02.A03.21.0011.

\section{References}

Allegret, J. P.,, Couharde, C., Guillaumin, C. (2012): The impact of external shocks in East Asia: Lessons from a structural VAR model with block exogeneity. Economie International 4(132), 35-89, https://doi.org/10.1016 /S2110-7017(13)60058-X.

Bakhtizin, A. R., Buchwald, E. M., Kolchugina, A. V. (2017): Economic differentiation of Russian regions: new assessments and patterns. ETAP, 1. Retrieved from https://cyberleninka.ru/article/n/ekonomicheskaya -differentsiatsiya-regionov-rossii-novye-otsenki -i-zakonomernosti (Accessed on September 16, 2018).

Beckworth, D. (2010): One nation under the FED? The asymmetric effects of US monetary policy and its implications for the United States. Journal of Macroeconomics 32(3), 732-746, https://doi.org /10.1016/j.jmacro.2009.12.001.

Blanchard, O. J., Quah, D. (1989): The Dynamics Effects of Agreggate Demand and Supply disturbances. American Economic Review 79(4), 655-673.

Briguglio, L., Cordina, G., Farrugia, N., Vella, S. (2009): Economic Vulnerability and Resilience Concepts and Measurements. Oxford Development Studies 37(3), 229-247, https://doi.org/10.1080/1360081090 3089893.

Bristow, G., Healy, A. (2015): Crisis response, choice and resilience: Insights from complexity thinking. Cambridge Journal of Regions, Economy and Society 8(2), 241-256, https://doi.org/10.1093/cjres/rsv002.

Burlachkov, V. K., Golovnin, M. Yu. (2014): External shocks to the economy and monetary system of Russia and Belarus: consequences and ways to overcome. Moscow, IE RAS.

Černíková, P. (2010): The analysis of supply and demand shocks adjustment dynamics of the EU-15 countries. Ekonomická revue - Central European Review of Economic Issues 13, 219-229, https://doi.org/10.7327 /cerei.2010.12.04.

Crescenzi, R., Luca, D., Milio, S. (2016): The geography of the economic crisis in Europe: national macroeconomic conditions, regional structural factors and short-term economic performance. Cambridge Journal of Regions, Economy and Society 9(1), 13-32, https://doi.org /10.1093/cjres/rsw001.

Crone, T. (2005): An Alternative Definition of Economic Regions in the United States Based on Similarities in State Business Cycles. Review of Economics and 
Statistics 87(4), 617-626, https://doi.org/10.1162 /003465305775098224.

Danilova, I. V., Zimmermann, O. A. (2014): Adaptive costs of regions in the conditions of Russia's accession to the WTO. Newsletter of the South Ural State University. Series: Economics and Management 3(8), 15-23.

Dominte, L. (2006): Determinants and effects of economic openness. Analele Stiintifice ale Universitatii "Alexandru Ioan Cuza" din Iasi (Alexandru Ioan Cuza University) 52, 243-245.

Engemann, K. M., Owyang, M. T., Wall, H. J. (2014): Where is an oil shock? Journal of Regional Science 54(2), 169-185, https://doi.org/10.1111/jors.12071.

Eraydin, A. (2016): The role of regional policies along with the external and endogenous factors in the resilience of regions. Cambridge Journal of Regions, Economy and Society 9(1), 217-234, https://doi.org/10.1093/cjres /rsv026.

Fraser, P., MacDonald, G. A., Mullineux, A. W. (2012): Regional monetary policy: an Australian perspective. Regional Studies 48(8), 1419-1433, https://doi .org/10.1080/00343404.2012.714897.

Frisch, R. (1933): Propagation Problems and Impulse Problems in Dynamic Economics (Economic Essays in Honour of Gustav Cassel, Allen and Unwin, London). The Foundations of Econometric Analysis, 333-346, https://doi.org/10.1017/CB09781139170116.032.

Hurst, H. E., Black, R. P., Simaika, Y. M. (1965): Long-Term Storage: An Experimental Study. Constable and Co. Ltd., London.

Masik, G. (2014): Economic resilience. The case study of Pomorskie Region. Economy and Business Journal 8(1), 72-83.

Masik, G. (2016): Economic resilience: the case of Poland and certain European regions. Geographia Polonica 89(4), 457-471, https://doi.org/10.7163/GPol.0068.

Norrbin, S. C., Schlagenhauf, D. E. (1996): The role of international factors in the business cycle: A multicountry study. Journal of International Economics 40(1-2), 85-104, https://doi.org/10.1016 /0022-1996(95)01385-7.

Ochkin, R. O. (2018): Theoretical and methodological aspects of studying external shocks as a determining factor of national and state economic interests. Theoretical Economics 2(44), 161-167.

Owyang, M. T., Wall, H. J. (2009): Regional VARs and the channel of monetary policy. Applied Economics Letters 16, 1191-1194, https://doi.org/10.1080 /13504850701367247.

Pesaran, M. H., Pierse, R. G, Lee K. C. (1993): Persistence, cointegration, and aggregation: a disaggregated analysis of output fluctuations in the U.S. economy. Journal of Econometrics 56, 57-88, https://doi.org /10.1016/0304-4076(93)90101-A.

Petrakos, G., Psycharis, Y. (2016): The spatial aspects of economic crisis in Greece. Cambridge Journal of Regions, Economy and Society 9(1), 137-152, https://doi.org /10.1093/cjres/rsv028.

Pilipenko, Z. A. (2011): Shocks and national economic systems: a mechanism for breaking down structural ties. Questions of Economics and Law 10, 55-60.
Pilipenko, O. I. (2015): Economic shocks and cyclical development of national financial systems. Newsletter of the RUDN University. Series: Economics 1, 103-111.

Regions of Russia (2017): Socio-economic parameters. Statistical collection. Retrieved from http://www.gks.ru /free_doc/doc_2017/region/reg-pok17.pdf.

Rutherford, T., Tarr, D. (2006): Regional Impacts of Russia's Accession to the WTO. Policy Research Working Paper. Retrieved from http://documents.worldbank.org /curated/en/675751468095997989/pdf /wps40150BOX0311113B01tell0JS0when0done1.pdf. https://doi.org/10.1596/1813-9450-4015.

Salamonsen, K. (2015): Exogenous Shocks as Drivers of Growth in Peripheral Regions. - A Multilevel Approach to Regional Development. The Business School at University of Nordland, Oslo.

Serkov, L. A. (2018): Analysis of the impact of structural shocks on endogenous variables of a compact regional dynamic model. Newsletter of the Ural Federation University. Economics and Management Series 17(3), 445-470.

Shen, X., Tsai, K. S. (2016): Institutional adaptability in China: local developmental models under changing economic conditions. World Development 87, 107-127, https://doi.org/10.1016/j.worlddev.2016 .06 .010 .

Slutsky, E. E. (1937): The Summation of Random Causes as the Source of Cyclic Processes. Econometrica 5(2), 105-146, https://doi.org/10.2307/1907241.

Tamegawa, K. (2012): Two-region DSGE analysis of regionally targered fiscal policy. The Review of Regional Studies 42, 249-263.

Vorontsovsky, A. V., Gilenko, E. V., Petrova, E. V. (2013): Problems of forecasting economic growth under external shocks. Finance and Business 1, 23-38.

Vorontsovsky, A. V., Dmitriev, A. L. (2014): Modeling of economic growth taking into account the uncertainty of macroeconomic factors: a historical overview, problems and development perspectives. Newsletter of St. Petersburg State University. Series 5: Economy 2, 5-31.

Vorontsovsky, A. V., Vyunenko, L. F. (2016): Forecasting the development of the economy based on the stochastic model of economic growth with a consideration of the turning point. Newsletter of St. Petersburg State University. Series 5: Economics 4, 4-32, https://doi.org /10.21638/11701/spbu05.2016.401.

World Bank (2006): IDA Countries and Exogenous shocks. International Development Association. Resource Mobilization (FRM) October 2006. Retrieved from http://documents.worldbank.org/curated/en /688251468045233773/pdf/37909.pdf.

World Bank (2013): Trade policy barriers. An obstacle to export diversification in Eurasia. The World Bank, Poverty Reduction and Economic Management Network, International Trade Department May 2013. Policy Research Working Paper 6434. Retrieved from http:// documents.worldbank.org/curated /en/193891467993726441/pdf/wps6434.pdf. 